\author{
Dr. sc. Mato Arlović, sudac \\ Ustavnog suda Republike Hrvatske
}

\title{
USTAVNI OKVIR DJELOVANJA USTAVNOG SUDA REPUBLIKE HRVATSKE ZA ISPITIVANJE I OCJENJIVANJE USTAVNOSTI PRAVNIH PRAZNINA ${ }^{1}$
}

\author{
UDK: 342 (497.5) \\ Izvorni znanstveni rad \\ Primljeno: 15. 12. 2016.
}

Svaki ustavnopravni poredak, kao svoj idealni cilj, ima želju da svojim izvorima prava uredi sva pitanja u društvenim odnosima koje treba regulirati. Tada bi drugim propisima ostavili samo prostor za razradu njihova ostvarenja, a pojedinačnim aktima samo konkretizaciju tih općih normi na pojedine odnose između fizičkih i pravnih osoba. Međutim, unatoč stalnom razvoju i unapređivanju ustavnopravnih poredaka te povećanju broja i vrsti općeobvezujućih formalnopravnih izvora, nikad nije moguće u cijelosti unaprijed pravno urediti sve odnose u društvu. Ovakva je situacija posljedica činjenice da se realni životni odnosi daleko brže razvijaju i mijenjaju. Sami po sebi složeniji su nego što to pravo može predvidjeti. Upravo je takvo stanje odlučujući razlog postojanja pravnih praznina unutar pravnoga sustava, i to onih koje zbog brzoga razvoja društvenih odnosa pravni sustav ne može jednako brzo pratiti pa ih nazivamo naknadnim pravnim prazninama. No, ne smije se zanemariti ni početne pravne praznine koje nastaju već kod donošenja pravnoga akta (norme), jer ga je, prilikom reguliranja društvenog odnosa na koji se taj općenormativni i pravnoobvezujući pravni akt odnosi, zakonodavac propustio urediti. U radu se razmatra određenje pojma pravna praznina, sa doktrinarnog aspekta te ustavnosudske prakse. Nastoji se sagledati utjecaj pravnih praznina na temeljne vrednote i načela ustavnopravnog poretka te na njega u cjelini. Zatim, koja je nadležnost hrvatskog Ustavnog suda u otkrivanju pravnih praznina te njegova uloga u njihovom otklanjanju iz ustavnopravnog poretka radi sprečavanja njihova djelovanja na nestabilnost ustavnopravnog poretka ugrožavanjem vladavine prava, pravne sigurnosti te načela ustavnosti i zakonitosti.

Ključne riječi: pravne praznine, praćenje ostvarivanja ustavnosti i zakonitosti, nadzor nad donošenjem propisa za izvršavanje Ustava, zakona i drugih propisa, ustavna tužba, ljudska prava i temeljne slobode, vladavina prava, ustavnost $i$ zakonitost, pravna sigurnost, izvješća

1 Rad je prezentiran na Međunarodnoj konferenciji na temu: „Uloga ustavnosudskih odluka u popunjavanju pravnih praznina i jačanju pravne sigurnosti“, u Jerevanu, Republika Armenija, 20. do 23. listopada 2016. 


\section{UVOD}

Svaki ustavnopravni poredak kao svoj idealni cilj želi pravnu situaciju u kojoj njegovi pravni izvori u cijelosti i dosljedno uređuju sva pitanja u društvenim odnosima koja treba pravno urediti. Međutim, unatoč stalnom razvoju pravne regulative i neprekidnom množenju propisa kojima se reguliraju društveni odnosi, iskustvo nas neupitno poučava da nikada u društvenim odnosima nije moguće sve do kraja predvidjeti i pravno urediti.

Posljedica takve situacije jest pojava pravnih praznina odnosno zakonodavnih propusta unutar pravnoga sustava. Slična je situacija i kada se segmentarno po svojim osobnostima analizira neki od društvenih odnosa i, dakako, pravni propis kojim se on regulira. Zapravo, pravnih praznina i zakonodavnih propusta mora biti, jednostavno zato što je život uvijek složeniji i brži u svom razvoju i promjenama nego što to pravo može pratiti. U tom smislu su pravne praznine odnosno zakonodavni propusti nužna posljedica nesavršenosti ustavnopravnog poretka. Samim time nedvojbeno je da one, manje ili više, postoje u svakom ustavnopravnom poretku. Postojanje pravnih praznina odnosno zakonodavnih propusta unutar ustavnopravnog poretka u načelu na općoj razini ima negativan utjecaj na njegovu konzistentnost, jedinstvenost i djelotvornost, te na realiziranje njegovih najviših vrednota, a osobito vladavine prava, pravne sigurnosti te ustavnosti i zakonitosti. U konkretnim društvenim odnosima postojanje pravnih praznina dovodi do nejednakosti pred zakonom, odnosno do nejednake primjene prava na istovrsne slučajeve čime u krajnjoj liniji dovodi do diskriminacije sudionika u pravnim odnosima.

Pravne praznine problem su s kojim se u svom radu sreću sva tijela koja provode, tumače i primjenjuju pravne propise u konkretnim slučajevima. Ta tijela problem pravnih praznina, postupajući u konkretnim slučajevima, nastoje riješiti interpretativnim metodama te metodom analogije, stvarajući pravilo koje će popuniti pravnu prazninu, sukladno cilju i duhu pravnog propisa u kojem je prisutna pravna praznina, tako da ne narušava načelo ustavnosti i zakonitosti, a, dakako, važi samo za taj slučaj. Ono, naime ne može i ne smije postati pravilo - izvor prava za rješavanje svih drugih istovrsnih ili sličnih slučajeva. Čak štoviše, ono ne može i ne smije biti obligatorno kao izvor prava ni za tijelo koje ga je stvorilo u rješavanju idućeg takvog ili sličnog slučaja koje će dobiti na rješavanje.

Drugim riječima, i to tijelo može na drugačiji način riješiti novi slučaj baš zbog toga što ovo pravilo kojim se popunjava pravna praznina, a do kojeg je došlo nadležno tijelo koje primjenjuje pravni akt u kojem je sadržana pravna praznina, nije izvor jer nije općeobvezujuća pravna norma donesena kao općenormativni pravni akt od strane nadležnoga tijela.

Pravne praznine nedopuštene su u području kaznenoga prava.

Pravne praznine, s obzirom na svoj utjecaj na temeljne vrednote ustavnopravnog poretka te na njegova načela kao što su vladavina prava, ustavnost i zakonitost, pravnu sigurnost te na ostvarivanje i zaštitu ljudskih prava i temeljnih sloboda jesu 
predmet interesa ne samo npr. građansko-pravnih već i ustavno-pravnih područja, a time postaju i predmet pažnje i ustavnog sudovanja.

U Republici Hrvatskoj odnos, nadležnost i postupanje Ustavnoga suda prema pravnim prazninama proizlazi iz koncepta po kojem su ustavno uređeni položaj, zadaće i nadležnosti Ustavnog suda.

Kad su u pitanju pravne praznine odnosno zakonodavni propusti, valja reći da hrvatski ustavnopravni poredak izrijekom ne poznaje ove pojmove niti daje ovlast Ustavnom sudu da ispituje i provodi ocjenu ustavnosti i zakonitosti pravnih praznina. Ustavni sud Republike Hrvatske i sam je zauzeo stajalište da o postojanju pravnih praznina nije nadležan odlučivati u postupcima ocjene ustavnosti zakona ni ustavnosti i zakonitosti drugih propisa, iako za njega i pravnu teoriju nije sporno da se u tim postupcima sreće s njima. Međutim, pravne praznine ne postoje samo u slučajevima nepostojanja pravne norme. One postoje i u slučajevima nepotpunosti i nedorečenosti pravne odredbe koja je zbog toga ustavno neprihvatljiva jer, primjerice, dovodi od nejednakosti između pravnih subjekata obuhvaćenih odredbom kojom je propisano određeno pravo onih subjekata koji to zbog propusta zakonodavca nisu, a trebali su biti. Sva ova i druga pitanja imaju i svoju ustavnu dimenziju, veoma značajnu za ostvarivanje ustavnosti i zakonitosti, te za zaštitu ljudskih prava i temeljnih sloboda zajamčenih Ustavom.

Time one jesu predmet interesa Ustavnog suda i ustavnog sudovanja. Kako i na koji način se s ovim pitanjima nosi Ustavni sud Republike Hrvatske? Koje su njegove nadležnosti u pogledu pravnih praznina i kako on svojim djelovanjem može utjecati na popunjavanje pravnih praznina, a time i na zaštitu načela ustavnosti i zakonitosti, te na ostvarivanje vladavine prava i pravne sigurnosti, bit će osnovna tematika kojom će se u nastavku baviti ovaj rad.

\section{O POJMU PRAVNE PRAZNINE}

Pitanjem pravnih praznina u Republici Hrvatskoj, primarno su se bavili i bave teoretičari prava i države. Radi što boljeg razumijevanja ove problematike izložit ću neka od teorijskih stajališta koja se odnose na pravne praznine. ${ }^{2}$

Profesor dr. sc. Berislav Perić u pristupu pravnim prazninama polazi od stava: "Uvijek će postojati slučajevi koji se ne mogu podvesti pod 'svoju' normu, jer je zakonodavac takav slučaj previdio (nije predvidio da će se pojaviti) ili ga je propustio (zaboravio) riješiti. Stoga u pravnom sustavu postoji 'poroznost' ('rupe') odnosno nedovršenost, neiskazanost. Te se pojave skupnim imenom nazivaju pravne praznine. To su pojave u pravu kad nastane jedan slučaj koji bi trebalo pravno obuhvatiti, regulirati i riješiti, a na raspolaganju nema potrebne pravne norme."”3

2 Vrlo dobar pregled doktrinarnog pristupa pojmu i vrstama pravnih praznina dao je Ustavni sud Republike Hrvatske u svom materijalu „Problemi zakonodavnih propusta u zakonodavnoj praksi“, Ustavni sud Republike Hrvatske broj: SuP-MS-2/2008. Navedeni materijal korišten je u izradi ovog rada.

3 Perić, B.:"Država i pravni sustav, Zagreb, 1994., str. 223-225. 
Pravnim prazninama detaljnije pristupa i još širi prostor posvećuje, u svojoj knjizi "Država i pravo", prof. dr. sc. Nikola Visković. On ih pojmovno određuje, utvrđuje zbog kojih uzroka se pojavljuju i daje jednu od mogućih podjela, uz istovremeno utvrđivanje njihova pojma te, temeljem njega, i razlikovanja. On piše:

„(...) u svakom društvu postoje određene vrste odnosa koji imaju spomenute tri osobine 'pravnosti' (da su važni za opstanak i dobrobit društva, da sadrže snažne sukobe interesa i da su izvanjski kontrolabilni), što upućuje na potrebu njihova pravnog normiranja, ali koji ipak ostaju ili posve pravno nenormirani ili nedostatno normirani. Takvi odnosi nazivaju se pravne praznine.

Do toga (...) dolazi uglavnom zbog dva uzroka:

Prvo, događa se prilikom obaranja jednog državnopravnog poretka (revolucijom, prevratom, odcjepljenjem) da normotvorci iz novog državnog poretka ne stvore odmah nove pravne norme umjesto svih onih koje su ukinute, tako da neki društveni odnosi ostanu neko vrijeme neregulirani. To je ipak rijetkost, barem u modernim društvima, jer novi normotvorci redovito izbjegavaju teške posljedice pravnih praznina tako što preuzimaju trajno ili pravne norme starog poretka, ili pak donose odmah nove norme umjesto onih koje ukidaju. Tako je npr. učinjeno i prilikom osamostaljivanja Republike Hrvatske od SFR Jugoslavije 1990. godine.

Drugi i češći uzrok pravnih praznina jest pojava novih vrsta društveno važnih i konfliktnih odnosa koje normotvorci nisu od početka kao takve prepoznali ili su ih zbog raznih razloga zakašnjelo normirali. To je uzrok koji izaziva najveći dio pravnih praznina u modernim društvima, gdje se ponajprije zbog tehničkog napretka sve češće i naglo javljaju novi odnosi koji se pred nekoliko desetljeća ili nekoliko godina nisu mogli naslutiti, pa ih stoga ni normotvorci nisu mogli od prvog pojavljivanja prepoznati niti procijeniti njihovu važnost. U suvremenom svijetu takvi su npr. odnosi iz područja: a) ekologije, b) zdravstva, c) bioetike i d) kulture.(...)

Pored tog osnovnog značenja termina 'pravna praznina', u pravnoj teoriji govori se još o tehničkim pravnim prazninama i o vrijednosnim pravnim prazninama. Za razliku od osnovnog značenja, gdje se praznina nalazi izvan pravne norme (kao odnos koji nije normiran), pravne praznine u ova dva značenja nalaze se unutar pravnih normi. Tehnička praznina sastoji se od nedostatnog normativnog zahvaćanja nekog pravnog odnosa, od slabog normativnog reguliranja, i to: a) ili zbog nedostajanja nekog važnog elementa norme, npr. nepropisivanje sankcije ili nadležnosti za poduzimanje pravnih radnji, b) ili zbog nejasnoća i neodređenosti pojmova kojima se norma iskazuje, npr. prilikom uporabe apstraktnih pojmova ili tzv. 'pravnih standarda' kao što su savjesnost, poštenje i povjerenje, uzdržavanje, nesuglasnost naravi. Vrijednosna praznina sastoji se pak od suda nekih subjekata da norma uređuje određeni društveni odnos nepravedno ili na drugi način vrijednosno 
manjkavo, te da je stoga treba promijeniti i uskladiti s vrijednostima koje zastupaju ti subjekti." ${ }^{4}$

Vrlo zanimljiv pristup pravnim prazninama, poglavito polazeći od uzroka njihova nastajanja ima prof. dr. sc. Đuro Vuković. On u svojoj knjizi Pravna država, o tome piše: „Praznine mogu nastati kada zakonodavac ne sagleda dovoljno materiju koju normira. Može se raditi i o nedovoljnom poznavanju nomotehnike. Nije niti isključeno, da zakonodavac namjerno ne regulira neko pitanje prepuštajući praksi da ovo riješi. Pravne praznine mogu se javiti kao početne, kada zakonodavac, donoseći opći akt, ne regulira sva pitanja. Do pravnih praznina može doći i naknadno zbog promijenjenih društvenih prilika, a zakonodavac ne prati dovoljno društvena kretanja i pravovremeno ne reagira." ${ }^{5}$

Sličan pristup pravnim prazninama ima i bosanskohercegovački teoretičar države i prava prof. dr. sc. Fuad Muhić. On u svojoj knjizi Teorija države i prava, pored inog, ovaj institut opisuje kao: „one situacije koje nisu regulisane opštom pravnom normom ali je njihov sadržaj od interesa za poredak, zbog čega on ima potrebu za njihovim naknadnim pravnim tretmanom. Nužnost postojanja pravnih praznina pojavljuje se iz najmanje dva razloga: što je život neuporedivo bogatiji od težnje poretka za sveobuhvatnošću te ga čini nemoćnim u pogledu egzaktnog predviđanja situacija koje će nastupiti; i što sam poredak, čak i kad bi imao približnu mogućnost predviđanja, ne raspolaže adekvatnim, tehničkim sredstvima za svaku pojedinačnu regulaciju."

Iz navedenog pregleda doktrinarnih pristupa problemu instituta pravnih praznina, razvidno je da među pravnim teoretičarima, unatoč nekim odstupanjima, zapravo u svojoj biti postoji relativno visoki stupanj suglasnosti oko pojmovnog određivanja pravne praznine, uzroka njezina nastajanja te vrsta na koje se mogu razlistati. U osnovi se pravna praznina svodi na nepostojanje ,pravila za rješavanje konkretnog slučaja“, odnosno konkretni društveni odnos koji treba pravno riješiti ulazi u one slučajeve „koji se ne mogu podvesti pod svoju normu, jer je zakonodavac takav slučaj previdio (nije predvidio da će se pojaviti) ili ga je propustio (zaboravio) riješiti." ${ }^{\text {"7 }}$ Međutim, prepoznavanje pravnih praznina i njihova diferenciranja od tzv. autonomnog prostora, koji zakonodavac pravno ne želi regulirati i prepušta ga autonomnom postupanju pravnih subjekata npr. u skladu s običajnim i tradicionalnim konvencionalnim pravilima ponašanja - nije lako, ali nije ni nemoguće. U provedbi ovog pravnog posla pravni stručnjaci polaze od prirode prava, upotrebom pravnih tehnika, smatra prof. dr. sc. Duško Vrban. Jednostavno zato, smatra on, što „do pravnih praznina dolazi samo pod sljedećim pretpostavkama: a) zakonodavac nije svjesno (namjerno) zaobišao neka bića, radnje i stanja; b) radi se o nekom važnom pravnom području ili pravnoj grani koja nije regulirana, a trebala bi to biti po svojoj prirodi i c) popunjavanje praznine neće proturječiti osnovnim načelima pravnog

4 Visković, N.: Država i pravo, Birotehnika, Zagreb, 1997., str. 218-220.

5 Vuković, Đ.: Pravna država, Zgombić i Partneri, Zagreb, 2005.., str. 107-108.

6 Muhić, F.: Teorija države i prava, Sarajevo, 1998., str. 326.

7 Perić B., Isto, str. 225. 
poretka te zemlje. Ako te pretpostavke nisu ispunjene, može se ustvrditi da postoji pravno irelevantan ili indiferentan prostor."Ukoliko se pak radi o prostoru društvenih odnosa koji nisu „,irelevantni“ ili „,indiferentni“, otvara se u rješavanju konkretnih pravnih odnosa pitanje njihova popunjavanja. Suci su u takvim situacijama ovlašteni tumačiti pravne propise i, primjenom metode analogije i drugih uobičajenih pravnih tehnika, promišljati i djelovati po vrijednosnim kriterijima. ${ }^{8}$

Ovdje, ipak, valja upozoriti da pronađena pravna norma kojom će se popuniti pravna praznina u rješavanju konkretnog slučaja, nije u pravnoformalnom smislu novi izvor prava, iako može biti osnova za rješavanje drugih konkretnih slučajeva u sudskoj ili upravnoj praksi. Hoće li se ta pravna norma koristiti ili neće, ovisit će o nahođenju tijela koje treba riješiti konkretni slučaj, ali bez obveze prihvaćanja. Čak štoviše, takva pravna norma ne obvezuje ni sam organ (npr. sud) koji ju je donio u rješavanju idućih konkretnih slučajeva. Naime, i sud može na drugačiji način riješiti sljedeći „novi“" slučaj.

Kad su u pitanju društveni odnosi koje uređuje krivično pravo, nema dvojbe kod teoretičara pravnih znanosti, pa i po izričitim kaznenim zakonima, da u Europi ne može postojati pravna praznina. Naime, u ovom području društvenih odnosa, polazeći od načela vladavine prava, pravne sigurnosti te ustavnosti i zakonitosti, načela koja se za ovo područje primjenjuju u najstrožem obliku, osobito radi zaštite ljudskih prava i temeljnih sloboda - pravne praznine su nedopustive. To proizlazi iz zahtjeva propisivanja kaznenih djela isključivo zakonom, odnosno poštovanja stare maksime rimskoga prava: nulum crimen nula pene sine lege.

\section{USTAVNI OKVIR ODNOSA USTAVNOG SUDA PREMA PRAVNIM PRAZNINAMA}

Na konzistentnost ustavnopravnog poretka, ostvarivanje ustavnosti i zakonitosti, ali i u konkretnim slučajevima koje rješavaju nadležna tijela, ostvarivanje zahtjeva da su svi jednaki pred zakonom te da se na istovrsne slučajeve zakon jednako primjenjuje, i te kakvog utjecaja mogu imati i imaju pravne praznine.

Zbog toga se one ne mogu i ne smiju zaobići ni kod ustavnog sudovanja koje provode ustavni sudovi. Oni se s pravnim prazninama sreću, htjeli ne htjeli, kako u postupcima apstraktne kontrole ustavnosti i zakonitosti, tako postupajući i u konkretnim ustavnim sporovima po osnovi ustavne tužbe ispitujući i odlučujući o povredi ljudskih prava i temeljnih sloboda zajamčenih ustavom. Dakako, koji će biti oblik i sadržaj ustavnosudskog postupanja ustavnih sudova po pitanjima pravnih praznina, određeno je i propisano odgovarajućim pravnim aktima (u Republici Hrvatskoj isključivo ustavne snage i ustavne prirode) kao što su neka od nadležnosti Ustavnoga suda.

8 Vrban D.: Država i pravo, Golden marketing, Zagreb, 2003., str. 462. 
Nadležnost Ustavnog suda Republike Hrvatske uređena je normama ustavne snage, odnosno uređuju je Ustav i Ustavni zakon o Ustavnom sudu koji ima snagu jednaku Ustavu jer se on, voljom ustavotvorca propisanom u članku 132. Ustava, „donosi po postupku propisanom za promjenu Ustava."

Neki autori smatraju (npr. Smerdel, B. i Sokol, S. takvu su podjelu djelatnosti učinili u svojoj knjizi: Ustavno pravo, Zagreb, 2003.) da je moguće podijeliti djelatnosti Ustavnog suda Republike Hrvatske koje proizlaze iz njegove nadležnosti na osnovne i ostale nadležnosti određene Ustavom.

Osnovne bi bile one koje su izrijekom nabrojane u članku 129. Ustava, a čine ih nadležnost da:

- odlučuje o suglasnosti zakona s Ustavom;

- odlučuje o suglasnosti drugih propisa s Ustavom i zakonom;

- može ocjenjivati ustavnost zakona te ustavnost i zakonitost drugih propisa koji su prestali važiti ako od tog prestanka do podnošenja zahtjeva ili prijedloga za pokretanje postupka nije prošlo više od godine dana;

- odlučuje povodom ustavnih tužbi protiv pojedinačnih odluka državnih tijela, tijela jedinica lokalne i područne (regionalne) samouprave te pravnih osoba s javnim ovlastima kad su tim odlukama povrijeđena ljudska prava i temeljne slobode, kao i pravo na lokalnu i područnu (regionalnu) samoupravu zajamčeni Ustavom Republike Hrvatske;

- prati ostvarivanje ustavnosti i zakonitosti te o uočenim pojavama neustavnosti i nezakonitosti izvješćuje Hrvatski sabor;

- rješava sukob nadležnosti između tijela zakonodavne, izvršne i sudbene vlasti;

- odlučuje, u skladu s Ustavom, o odgovornosti predsjednika Republike;

- nadzire ustavnost programa i djelovanja političkih stranaka i može, u skladu s Ustavom, zabraniti njihov rad;

- nadzire ustavnost i zakonitost izbora i državnog referenduma i rješava izborne sporove koji nisu u djelokrugu sudova;

- obavlja druge poslove određene Ustavom. ${ }^{10}$

Ti drugi poslovi, kako ih naziva ustav, zapravo su formalno i sadržajno dio nadležnosti Ustavnog suda Republike Hrvatske. I oni su određeni normama samog Ustava, ali nisu sadržane u članku 129., već u odredbama drugih članaka koji uređuju pojedina pitanja u ustavnoj strukturi, a iz supstincijalnosti tog ustavnog odnosa proizlazi potreba, kad se za to steknu ustavom propisane okolnosti, za djelovanjem Ustavnog suda Republike Hrvatske.Evo tih nadležnosti:

- Opći nadzor za donošenje propisa (zakona i drugih propisa) za izvršenje odredaba Ustava ako Ustavni sud utvrdi da nadležno tijelo nije donijelo takav

9 Ustav Republike Hrvatske, članak 132. stavak 2., Narodne novine broj 85/2010. - pročišćeni tekst.

10 Članak 129. Ustava Republike Hrvatske, Narodne novine broj 85/2010. - pročišćeni tekst. 
propis a bilo je dužno donijeti ga, ,o tome obavještava Vladu, o propisima koje je bila dužna donijeti Vlada, obavještava Hrvatski sabor"; ${ }^{\text {"11 }}$

- $\quad$ Primanje svečane prisege Predsjednika Republike, kojom se obvezuje na vjernost Ustavu; ${ }^{12}$

- Donošenje odluke o postojanju okolnosti da je Predsjednik Republike spriječen obavljati svoju dužnost zbog bolesti ili neposrednosti i kad predsjedničke dužnosti privremeno preuzima predsjednik Hrvatskog sabora; ${ }^{13}$

- Donosi odluke o nastupanju okolnosti kao što je smrt, ostavka ili odluka samog Ustavnog suda o odgovornosti Predsjednika Republike Hrvatske za povredu Ustava, kada mu prestaje mandat, a dužnost privremeno preuzima predsjednik Hrvatskog sabora; ${ }^{14}$

- Odlučuje o prethodnom odobrenju o pritvoru ili pokretanju kaznenog postupka protiv Predsjednika Republike, ${ }^{15}$

- $\quad$ Odlučuje o žalbi suca protiv odluke o razrješenju; ${ }^{16}$

- Donosi odluku o žalbi protiv odluka Državnog sudbenog vijeća o disciplinskoj odgovornosti suca: ${ }^{17}$

- Odlučuje o ustavnosti referendumskog pitanja o kojem se temeljem narodne inicijative zahtijeva raspisivanje referenduma. ${ }^{18}$

Iz citiranih odredbi Ustava i Ustavnog zakona o Ustavnom sudu Republike Hrvatske uočljiva je vrlo široka nadležnost Ustavnog suda, no, usprkos tome, razvidno je da niti jedan od ova dva pravna akta (a jedino oni uređuju nadležnost Ustavnog suda) izričito, odnosno expressis verbis ne utvrđuje njegovu nadležnost da ispituje i ocjenjuje ustavnost pravnih praznina, odnosno zakonodavnih propusta u ustavnopravnom poretku. To, dakako, ne znači da se Ustavni sud Republike Hrvatske u svojoj ustavnosudskoj praksi nije susretao s problemom zakonodavnog propusta odnosno pravne praznine te o njima zauzimao stajališta. On je to prije svega mogao i morao učiniti polazeći od svoje zadaće da ,jamči poštovanje i primjenu Ustava Republike Hrvatske i svoje djelovanje temelji na odredbama Ustava Republike Hrvatske i Ustavnog zakona o Ustavnom sudu Republike Hrvatske. " ${ }^{19}$

Drugim riječima, Ustavni sud svoju nadležnost utvrđenu u Ustavu i Ustavnom zakonu o Ustavnom sudu Republike Hrvatske i po sili Ustavnog zakona mora temeljiti na njihovim odredbama, ali je k tome još značajnije da to djelovanje mora

11 Isto, članak 130.

12 Isto, članak 95. stavak 6.

13 Isto, članak 97. stavak 2.

14 Isto, članak 97. stavak 3.

15 Isto, članak 106. stavak 2.

16 Isto, članak 123. stavak 3.

17 Isto, članak 123. stavak 4.

18 Isto, članak 95.

19 Članak 2. stavak 1. Ustavnog zakona o Ustavnom sudu Republike Hrvatske, Narodne novine broj 49/2002. - pročišćeni tekst. 
biti utemeljeno na najvišim vrednotama ustavnog poretka Republike Hrvatske jer su one temelj za tumačenje Ustava. ${ }^{20} \mathrm{Uz}$ ine najviše vrednote, u ovom slučaju su nešto istaknutije one koje se tiču vladavine prava i poštovanje prava čovjeka. U tom smislu svaka pravna praznina odnosno zakonodavni propust kojim su povrijeđene najviše vrednote, bilo na izravan, bilo na neizravan način, jesu ustavno pitanje koje ulazi u nadležnost Ustavnoga suda.

Zapravo, indirektna nadležnost Ustavnog suda glede pravnih praznina proizlazi upravo iz direktne njegove zadaće da jamči poštovanje i primjenu Ustava tumačeći njegove pojedine odredbe i njega kao cjelinu, polazeći od najviših vrednota ustavnoga poretka. To je, za pristalice teorijskog koncepta o sudskom aktivizmu, istovremeno osnova i za njegovu primjenu u postupanju Ustavnog suda kad se susreće s pitanjem pravnih praznina. Tako B. Smerdel o tom problemu piše: „Credo sudačkog aktivizma glasi: Ako u zakonu postoji pravna praznina, ustavni suci su je dužni popuniti pravnim shvaćanjem utemeljenim na njihovom razumijevanju ustavnih odredbi i načela. ... Teleološka metoda, kao najvažnija metoda interpretacije (J. Barbić), ... Polazeći od cjeline ustavnog teksta i važećih izvora međunarodnog prava, kombinacijom s ostalim metodama interpretacije, omogućuje u većini slučajeva izvesti tumačenje kojim će se nejasne ili nepotpune odredbe zakona prilagoditi ustavom utvrđenim ciljevima." ${ }^{21}$ Tada, smatra prof. dr. sc. S. Sokol, jedan od bivših predsjednika Ustavnog suda Republike Hrvatske, u slučaju utvrđenja pravnih praznina treba voditi računa o tome da se one popune, ali tako da ne dođe do povrede načela (a u ustavnopravnom poretku i jedne od najviših njegovih vrednota) vladavine prava. On polazi od toga da je s pravom „,načelo vladavine prava prihvaćeno i razrađeno od Ustavnog suda kao temeljni zbirni kriterij u pristupu ustavnoj interpretaciji. Sukladno tome, ono je cilj koji u konkretnom slučaju ustavne interpretacije može pružiti uporište Ustavnom sudu da ocijeni neustavnom neku zakonsku odredbu zbog pravne praznine pri regulaciji dotičnog odnosa koji, primjerice, dovodi do nejednakosti odnosno diskriminira određenu skupinu. To je, mislimo, i ona krajnja crta dalje od koje Ustavni sud, i kad je riječ o vladavini prava, ne bi smio ići kako se ne bi pretvorio u zakonodavca. Zbog toga smatramo da Ustavni sud ne bi smio, a teško bi i mogao, intervenirati ukidnom odlukom u slučaju kad je zakonodavac uopće propustio regulirati neki društveni odnos ili odnose, što znači da ne postoji nikakva zakonska odredba unutar koje bi se nalazila ili uz koju bi se mogla vezati pravna praznina." ${ }^{22}$

Navedeno stajalište i sam podržavam, iako moram reći, u sadržajnom smislu, da je prije njega, u praksi Ustavnog suda Republike Hrvatske, bilo odstupanja. Istini za volju, zbog ustavnopravne situacije koja je Ustavni sud dovela, moglo bi se reći, u stanje nužde. Naime, nakon osamostaljenja Republike Hrvatske, Ustavni sud bio je prinuđen tumačenjem pojedinih pravnih odredbi rješavati pravne praznine koje su

20 Članak 3. Ustava Republike Hrvatske.

21 Smerdel, B.: „Ustavno uređenje europske Hrvatske“, Narodne novine, Zagreb, 2013., str. 90.

22 Sokol, S.: „Ustavni sud Republike Hrvatske u zaštiti i promicanju vladavine prava“, Zbornik Pravnog fakulteta u Zagrebu, broj 6/2001., str. 1163. 
tada postojale u odredbama što su uređivale postupak pred njime. Prvim Ustavnim zakonom o Ustavnom sudu Republike Hrvatske, postupovna pitanja nisu bila razjašnjena, uz to što su bila nedostatna, te je u tom dijelu postojala pravna praznina. Da bi mogao postupati, Ustavni sud je neka postupovna pitanja važna za svoje postupanje morao razjasniti kroz tumačenje postupovnih odredbi u svojoj praksi, a neka pitanja za koja nije mogao naći interpretacijom odgovore autonomno je regulirao svojim Poslovnikom da bi mogao postupati u ustavnosudskim predmetima.

$\mathrm{Na}$ upite i prigovore da je ušao u područje pozitivnog zakonodavca koji su isticani i u prijedlogu za ocjenu ustavnosti pojedinih odredbi svog Poslovnika, Ustavni je sud odgovorio rješenjem broj: U-I-252/95 od 16. svibnja 1995. U tom predmetu Javni pravobranitelj Republike Hrvatske pokrenuo je postupak za ocjenu ustavnosti i zakonitosti članka 53. stavka 2. Poslovnika Ustavnog suda Republike Hrvatske (Narodne novine broj 29/94.; dalje: Poslovnik).

„Podnositelj prijedloga smatra da je navedena odredba u suprotnosti s odredbom članka 127. stavka 3. Ustava Republike Hrvatske te člancima 1. i 18, a u svezi sa člancima 28. - 30. Ustavnog zakona. Ovo zato jer da je članak 53. Poslovnika norma materijalnopravne prirode i ne može se svesti pod pojam propisivanja unutarnjeg ustrojstva Suda.

Nadalje ukazuje da nomotehnička metoda Ustavnog zakona o Ustavnom sudu Republike Hrvatske ne predviđa privremeno obustavljanje izvršenja pojedinačnog akta koji se osporava ustavnom tužbom, jer je ta mogućnost predviđena samo u odnosu na pojedinačni akt zasnovan na zakonu ili drugom propisu čija se ustavnost odnosno zakonitost ocjenjuje, dok u glavi IV. koja nosi naslov: 'Zaštita ustavnih sloboda i prava čovjeka i građanina' takva mogućnost nije predviđena.

Daljnju potkrjepu tom stajalištu prijedlog nalazi i u jezičnoj neusklađenosti jer Ustavni zakon u članku 18. koristi pojam 'privremeno obustaviti izvršenje', a Poslovnik u članku 53. stavku 2. 'odgoditi izvršenje'.

U osporenom dijelu Poslovnik je prema stajalištu podnositelja prijedloga postavljen kao pravni akt viši od Ustavnog zakona, iako temeljem članka 70. u svezi sa člankom 80. Ustava Republike Hrvatske u hijerarhiji pravnih akata dolazi tek na peto mjesto.

Na osnovi navedenoga predlaže da Ustavni sud Republike Hrvatske ukine članak 53. stavak 2. Poslovnika.

Prijedlog nije osnovan.

Dužnosti i rad Ustavnog suda određeni su ne samo odredbom članka 125. Ustava Republike Hrvatske koja određuje nadležnost već sveukupnim ustavnim određenjem, ustrojem državne vlasti u kojem Ustavni sud ima poseban položaj i ovlasti izvan zakonodavne, izvršne i sudbene, kako je to određeno člankom 4. Ustava Republike Hrvatske.

Ustav i Ustavni zakon ustavne ovlasti i položaj Suda odredile su tako da mu nije nadređeno niti jedno tijelo državne vlasti. Jedini ovlašten na uređenje ovlasti 
Ustavnog suda je, dakle, Sabor Republike Hrvatske u postupku za donošenje Ustava i Ustavnog zakona.

Člankom 127. stavkom 3. Ustava obvezuje se Ustavni sud Republike Hrvatske da unutarnje ustrojstvo uredi poslovnikom.

Stavak 1. istog članka određuje materiju koja se uređuje ustavnim zakonom pa su navedena i 'druga pitanja važna za izvršavanje dužnosti Ustavnog suda'.

To određenje sadrži i članak 1 . Ustavnog zakona u tekstu 'pitanja vezana za izvršenje dužnosti i rad Ustavnog suda'.

Pod unutarnjim ustrojstvom valja smatrati, uz pitanja koja su uobičajeni sadržaj Poslovnika, i sva druga pitanja od značaja za uspješan rad i izvršavanje uloge Ustavnog suda koja mu je određena Ustavom Republike Hrvatske i Ustavnim zakonom o Ustavnom sudu Republike Hrvatske.

Ustavni zakon je regulirao neka od pitanja koja su definirana u članku 127. stavku 1. Ustava. Neka od tih pitanja, bitna za izvršavanje dužnosti i rad Ustavnog suda, uređena su samo načelno te je konkretno rješavanje ostalo u obvezi Suda. U obvezi da ta pitanja rješava, odnosno da ih uredi tako da izvršava svoju dužnost u skladu sa svojim ustavnim položajem i ovlastima.

Ustavni zakon u poglavlju o zaštiti ustavnih sloboda i prava čovjeka i građanina sadrži svega tri članka o ustavnoj tužbi (članci 28. do 30.) a u njima se uređuje samo pitanje dopustivosti podnošenja, prekluzivnog roka za podnošenje tužbe te sadržaj odluke Ustavnog suda u povodu ustavne tužbe.

Na temelju tako oskudnog procesnopravnog uređenja ne može se provesti niti jedan postupak u povodu ustavne tužbe. Zbog toga je Ustavni sud, suočen s pravnom prazninom u pogledu procesnih normi za postupanje u ustavnosudskim stvarima, bio ovlašten i dužan procesne norme stvarati u tijeku konkretnih postupaka.

Provodeći konkretne postupke Ustavni sud je, dakle, kreirao procesna pravila po kojima će postupati i to na način da u postupku povodom ustavnih tužbi koristi odgovarajuća procesna pravila iz drugih procesnih zakona (Zakon o parničnom postupku, Zakon o općem upravnom postupku, Zakon o krivičnom postupku i dr.) a u nekim slučajevima - uvažavajući posebnosti postupka pred Ustavnim sudom - i stvarati nova pravila za svoje postupanje.

Slični postupci primjenjuju se i pred drugim sudovima i tijelima koja imaju javne ovlasti, s tom razlikom što su eventualne pravne praznine u drugim procesnim zakonima relativno rijetka pojava i ne odnose se na takvu širinu procesnih pitanja kao što je to u postupku povodom ustavne tužbe po Ustavnom zakonu.

Naravno da se Ustavni sud smatra vezanim procesnim pravilima koje je na gore opisani način sam u svojoj praksi stvarao, te je na taj način Sud postupao od samog početka svog djelovanja, pa do donošenja svog Poslovnika. Opisani način postupanja mogao se i nastaviti, ali sama osnova postupanja pred Ustavnim sudom sadrži ustavni zahtjev pravne sigurnosti onih koji se tom Sudu obraćaju za ustavnopravnu zaštitu. 
Naime, sistem tzv. precedenata vezuje Sud koji poznaje ta svoja precedentna procesna pravila, no za građane koji se obraćaju Ustavnom sudu takav način rada izaziva znatne probleme, jer se od njih ne može očekivati poznavanje prakse Ustavnog suda.

Zato je korisno da se procesna pravila, uobličena u dosadašnjim postupcima, na adekvatan način saberu, propišu i javno objave.

To je i razlog zbog kojeg je Ustavni sud među svoje poslovničke norme uvrstio i niz procesnih pravila. Time je Sud ograničio samoga sebe, jer je dužan postupati po pravilima koje je sam stvorio; ali, što je još važnije, ta procesna pravila sada su objavljena u službenom glasilu Republike Hrvatske - 'Narodnim novinama', dostupna su svima pa je time osigurana i pravna sigurnost građana i drugih pravnih subjekata koji se obraćaju ili će se obratiti Ustavnom sudu za ustavnopravnu zaštitu.

U pogledu konkretne odredbe članka 53. stavka 2. Poslovnika (koja nije materijalno-pravne, kako tvrdi podnositelj prijedloga, već procesno-pravne naravi) valja konstatirati da se ona odnosi na institut koji predstavlja civilizacijski doseg procesnog prava. Zbog toga postoji potreba da se taj institut predvidi i u postupku pred Ustavnim sudom u povodu ustavne tužbe radi zaštite od moguće povrede temeljnih sloboda i prava čovjeka i građanina - ustavnih prava.

Privremeno odgađanje izvršenja odluka koje se osporavaju ustavnom tužbom ugrađeno je u ustavnosudsku praksu u interesu osobe koja traži ustavnopravnu zaštitu. To znači da je u cijelosti usklađeno s temeljnim ciljevima ustavnopravne zaštite, zaštitom temeljnih sloboda i prava čovjeka i građanina, koja je prema članku 125. alinea 3. u nadležnosti Ustavnog suda.

U protivnom, zaštita ustavnih prava - bez pravodobne prethodne odgode osporene odluke - u mnogo slučajeva bila bi bez stvarnih učinaka u oblasti ustavnih prava osobe koja zahtijeva njihovu zaštitu.

Iz izloženoga slijedi da je članak 53. Poslovnika u službi djelotvorne zaštite ustavnih prava.

Temeljem navedenoga proizlazi da po sadržaju i pravnoj logici odredba članka 53. ne odstupa od pravno logičke osnove članka 18. Ustavnog zakona.

Pri tome se upotrebljeni izraz (odgoda izvršenja) javlja kao pravni pojam koji izvire iz provjerene pravne terminologije, koja ne ostavlja prostora dvojbama, osobito kada se ima u vidu da se radi o zaštiti ustavnog prava određenog pojedinca ili određene pravne osobe. Zato se ne može govoriti o jezičnoj neusklađenosti koja bi mogla utjecati na ustavnost osporene odredbe Poslovnika.“"

Možda je svoje stajalište o popunjavanju ovih pravnih praznina Ustavni sud još jasnije iskazao i pozivom na citirano rješenje u svom rješenju broj: U-I-238/1995 i U-I-797/1997, od 11. lipnja 1998. I u ovim predmetima riječ je o postupku ocjene ustavnosti i zakonitosti Poslovnika, i to njegove glave treće - članka 22. do 71. Podnositelji prijedloga smatrali su da su osporene odluke Poslovnika u suprotnosti s odredbom (tadašnjeg) članka 127. stavka 1. i 3. Ustava Republike Hrvatske, stoga što je tim člankom Ustava izričito propisano da se postupak pred Ustavnim 
sudom uređuje Ustavnim zakonom. Ustavni sud nije prihvatio ni ove prijedloge predlagatelja, smatrajući ih neosnovanima.

U navedenim rješenjima zauzeo je stajališta kojima ističe: a) da je o ovom pitanju već rješavao rješenjem broj: U-I-252/1995 od 16. svibnja 1995. i b) da je „Sud, suočen s pravnom prazninom u pogledu pravila za postupanje u ustavnosudskim stvarima, bio ovlašten i dužan postupovne odredbe stvarati u tijeku konkretnih postupaka."

Navedena situacija u kojoj je Ustavni sud sam popunio pravnu prazninu, neovisno o tome što je to bilo njegovo ponašanje iz ,nužde“, po mom je mišljenju nesporno iskorak u području pozitivnog zakonodavca. No, taj je iskorak imao privremeni karakter jer je naknadno otklonjen novim Ustavnim zakonom o Ustavnom sudu koji je u svoj tekst prihvatio u ovim predmetima osporavane odredbe Poslovnika.

Pored navedenih situacija, Ustavni sud Republike Hrvatske ipak temeljem Ustava i Ustavnog zakona o Ustavnom sudu Republike Hrvatske ima nadležnost za postupanje i djelovanje, te na temelju njega, i za doprinošenje rješavanju problema pravnih praznina na ustavnopravno dopušten i odgovarajući način. Radi se o slučajevima koji proizlaze iz provođenja njegovih nadležnosti: a) praćenja ostvarivanja ustavnosti i zakonitosti, b) nadzora nad donošenjem propisa za izvršenje Ustava, zakona i drugih propisa; c) postupajući po ustavnoj tužbi radi zaštite ljudskih prava i temeljnih sloboda zajamčenih Ustavom.

Subjekti ni pokretanje samog postupka kojim bi Ustavni sud saznao o pravnim prazninama, odnosno o zakonodavnim propustima, izrijekom nisu posebno propisani. Načelno govoreći o tim pitanjima, Ustavni sud Republike Hrvatske dobiva saznanja iz podnesaka podnositelja kojim oni putem zahtjeva ili prijedloga pokreću odnosno predlažu pokretanje postupaka za ocjenu ustavnosti zakona, te za ocjenu ustavnosti i zakonitosti drugih propisa, bez obzira na to pozivaju li se oni na pravnu prazninu. Slična je situacija i kod praćenja ostvarivanja ustavnosti i zakonitosti, te nadzora nad donošenjem propisa za izvršenje Ustava, zakona i drugih propisa. Ustavnosudska praksa Ustavnoga suda zauzela je stajalište da u smislu odredbi članaka 104. i 105. Ustavnog zakona o Ustavnom sudu prijedlog postupaka za ispitivanje pravnih praznina može pokrenuti svaka fizička i pravna osoba koja je nadležna za pokretanje postupka za ostvarivanje ovih nadležnosti Ustavnog suda. Razumljivo je samo po sebi da u povodu svih ovih postupaka Ustavni sud po svojoj inicijativi može pokrenuti postupak ispitivanja postojanja pravnih praznina odnosno zakonodavnog propusta i nakon njegova okončanja donijeti odgovarajuće odluke te poduzeti potrebne radnje.

Analogna situacija u vezi s pokretanjem ispitivanja postojanja pravne praznine odnosno zakonska zabrana stoji i u slučajevima koji se otvaraju u povodu postupanja po ustavnoj tužbi za zaštitu ljudskih prava i temeljnih sloboda. Dakako, uvijek imajući u vidu tko su ovlašteni subjekti za podnošenje ustavnih tužbi. 


\section{PRAĆENJE OSTVARIVANJA USTAVNOSTI I ZAKONITOSTI I PRAVNE PRAZNINE}

Ustavni sud Republike Hrvatske, temeljem članka 129. stavka 5. Hrvatskog ustava, u djelokrugu svoga djelovanja ima i nadležnost praćenja ustavnosti i zakonitosti te o uočenim pojavama neustavnosti i nezakonitosti izvješćivanja Hrvatskog sabora. Način njegova postupanja u ostvarivanju ove nadležnosti uređen je odredbama sadržanima u članku 104. Ustavnog zakona o Ustavnom sudu Republike Hrvatske. Ustavni sud ovu svoju nadležnost ostvaruje u sklopu redovitog praćenja ostvarivanja ustavnosti i zakonitosti, pa u tom postupku uočene pojave neustavnosti i nezakonitosti uoči i one kojima je pravna praznina neke zakonske odredbe pri regulaciji određenog društvenog odnosa dovela da neustavnosti i nezakonitosti zbog diskriminacije i nejednakosti određene skupine fizičkih ili pravnih osoba. Tu je riječ o situaciji sličnoj onoj kad Ustavni sud, provodeći postupak ocjene ustavnosti zakona, odnosno ocjene ustavnosti i zakonitosti drugog propisa, povodom tog postupka na vlastitu inicijativu, temeljem članka 129. stavka 6. Ustava i članka 104. Ustavnog zakona o Ustavnom sudu, odluči da Hrvatskom saboru podnese izvješće o uočenoj neustavnosti i/ili nezakonitosti. U tom izvješću uopće se izričito ne spominju pravne praznine, već se izvješćuje Hrvatski sabor kako zbog uočene neustavnosti i nezakonitosti postoji potreba za dopunom pojedinih zakonskih odredaba. Tako je npr. u postupku ocjene ustavnosti Zakona o mirovinskom osiguranju, u predmetu U-I-1152/2000 i dr., odlučio da će izvijestiti Hrvatski sabor o uočenoj pojavi neustavnosti. Neustavnost se očitovala u nejednakom pravnom položaju u ostvarivanju prava na obiteljsku mirovinu članova obitelji, izvanbračnih udovica, odnosno udovaca, u odnosu na članove obitelji bračne udovice odnosno udovce.

Budući da Ustavni sud ne ukida zakone ni druge propise odnosno pojedine njihove odredbe kad u postupku ocjene njihove ustavnosti, odnosno ustavnosti i zakonitosti utvrdi određenu pravnu prazninu odnosno zakonodavni propust, on onda u svojem izvješću upozorava Hrvatski sabor o potrebi dopune pojedinih odredbi ili otklanjanja zakonodavnog propusta. To je u gornjem slučaju vezanom uz predmet ocjene ustavnosti Zakona o mirovinskom osiguranju učinio u Izvješću broj: U-X1457/2007 od 18. travnja 2007., u čijem obrazloženju navodi:

„U Republici Hrvatskoj obitelj je pod osobitom zaštitom države, pa predstavlja zaštićeno ustavno dobro. S druge strane, brak i izvanbračna zajednica su Ustavom priznate zajednice. U odnosu na obitelj, Ustav ne čini razlike između bračne i izvanbračne zajednice. Obje vrste zajednica Ustavom su priznate i obje vrste uređuju se zakonom.

Polazeći od članka 61. Ustava koji priznaje dvije zajednice obitelji (bračnu i izvanbračnu), a uvažavajući pravnu narav i svrhu obiteljske mirovine u sustavu mirovinskog osiguranja (v. točku 1. ovog Izvješća), Ustavni sud utvrđuje da bi ZOMO-om trebale biti uređene i pretpostavke za stjecanje prava na obiteljsku 
mirovinu ne samo bračnim udovicama, odnosno udovcima, već i izvanbračnim udovicama, odnosno udovcima.

4. Pri razmatranju problema vezanih uz priznavanje prava na obiteljsku mirovinu izvanbračnim udovicama, odnosno udovcima, Ustavni sud je uvažio i činjenicu da su pravni učinci izvanbračne zajednice žene i muškarca uređeni Obiteljskim zakonom (Narodne novine, broj 116/03., 17/04. i 136/04.), te da u području nasljednih odnosa ostavitelja na temelju zakona nasljeđuje i njegov izvanbračni drug koji je u pravu nasljeđivanja izjednačen s bračnim (članak 8. stavak 2. Zakona o nasljeđivanju, Narodne novine, broj 48/03.).

Iako navedeni zakoni nisu neposredno primjenjivi u sustavu mirovinskog osiguranja uređenog ZOMO-om, oni predstavljaju okvir za uređenje prava na obiteljsku mirovinu izvanbračnim udovicama, odnosno udovcima u tom sustavu.

5. Ustavni sud na kraju ističe da je položaj užeg člana obitelji, a time i pravo na obiteljsku mirovinu izvanbračnim udovicama, odnosno udovcima izrijekom priznato Zakonom o pravima hrvatskih branitelja iz Domovinskog rata i članova njihovih obitelji (Narodne novine, broj 174/04.; u daljnjem tekstu: ZPHB).

Položaj člana uže obitelji smrtno stradalog, zatočenog ili nestalog hrvatskog branitelja priznaje se onom izvanbračnom drugu koji je do smrti, zatočenja ili nestanka branitelja živio s njim/njom u zajedničkom kućanstvu najmanje tri godine, pri čemu se status izvanbračne zajednice, u svrhu utvrđivanja prava priznatih ZPHB-om, utvrđuje u izvanparničnome sudskom postupku (članak 6. stavci 2. i 3. ZPHB-a).

6. Pođe li se od činjenice da se sredstva za ostvarivanje prava priznatih ZPHB-om (uključujući i prava na obiteljsku mirovinu) osiguravaju iz državnog proračuna (članak 106. ZPHB-a), pa se stoga može govoriti o svojevrsnoj državnoj mirovini priznatoj (i) izvanbračnim drugovima kao članovima uže obitelji smrtno stradalog, zatočenog ili nestalog hrvatskog branitelja, Ustavni sud tim više smatra osnovanim u sustavu mirovinskog osiguranja uređenog ZOMO-om priznati položaj člana obitelji i izvanbračnom drugu umrlog osiguranika, jer se taj sustav temelji na financiranju putem doprinosa osiguranika.

Ustavni sud pritom napominje da je uređivanje svih pitanja vezanih uz stjecanje prava na obiteljsku mirovinu izvanbračnog druga osiguranika (primjerice, koja će se životna zajednica žene i muškarca smatrati izvanbračnom u smislu ZOMO-a, na koji će se način ona dokazivati, pod kojim će se posebnim uvjetima pravo na obiteljsku mirovinu priznavati izvanbračnom drugu osiguranika, u kojem opsegu, itd.), u nadležnosti Hrvatskog sabora u skladu s člankom 2. stavkom 4. alinejom 1. Ustava. 
7. Sukladno navedenom, Ustavni sud izvješćuje Hrvatski sabor o potrebi dopune ZOMO-a radi uređenja zakonskih pretpostavki za priznavanje prava na obiteljsku mirovinu i izvanbračnoj udovici, odnosno udovcu osiguranika, kao članu njegove obitelji.“

Drugi slučaj specifičan je po tome što je posljedica odluke Ustavnog suda kojom je ukinut zakon odnosno pojedine njegove odredbe, a pravna praznina odnosno zakonodavni propust nastala je zbog toga što zakonodavac nije donio novi zakon, odnosno nije izmijenio ni dopunio ukinute odredbe, a ukidajuća odluka stupila je na snagu. U cijeloj dosadašnjoj praksi Ustavni sud Republike Hrvatske imao je samo jedan takav slučaj. Naime, Ustavni sud je 31. ožujka 1998. godine donio odluku broj: U-I-762/1996 kojom je ukinuo odredbu članka 40. stavka 2. Zakona o najmu stanova (Narodne novine broj 91/96.). Tom odlukom odredio je da ukinuta zakonska odredba prestaje važiti istekom roka od šest mjeseci od dana objave odluke u Narodnim novinama.

Hrvatski sabor u navedenome roku nije uskladio Zakon o najmu stanova s odlukom Ustavnog suda, a njezinim stupanjem na snagu prestala je važiti odredba članka 40. stavka 21., što je za posljedicu imalo nastajanje pravne praznine. Kako ni nakon više godina Hrvatski sabor nije uskladio taj Zakon s navedenom odlukom Ustavnog suda, Sud je Hrvatskom saboru uputio Izvješće broj: U-X-2191/2007 (Narodne novine broj 67/2007.), kojim ga izvješćuje o uočenoj neustavnosti i postojanju pravne praznine. U navedenom Izvješću Ustavni sud Republike Hrvatske pored inog ističe:

„Ustavni sud je u odluci o ukidanju odredbe članka 40. stavka 2. Zakona o najmu stanova (t. III.12.) iskazao sljedeće stajalište:

'Osporenom se odredbom uvjetuje pravo najmodavca da zaštićenom najmoprimcu otkaže ugovor o najmu stana kad u taj stan želi useliti sam ili namjerava useliti svoje potomke, roditelje ili osobe koje je prema posebnim propisima dužan uzdržavati, osiguravanjem najmoprimcu drugog useljivog stana pod uvjetima za stanovanje koji nisu nepovoljniji za najmoprimca, dakle na isti način kao što je to propisano u članku 21. stavku 2. Zakona o najmu, za koju je Sud utvrdio da nije suglasna Ustavu. Stoga i ovdje stoje razlozi koji su navedeni pod III.6., zbog čega ju je i kao nedovoljno selektivnu trebalo ukinuti i glede zaštićenih najmoprimaca, no zbog njezine povezanosti s odredbom stavka 1. istoga članka trebalo je učinak njezinog ukidanja odgoditi u smislu odredbe članka 21. stavka 2. Ustavnog zakona o Ustavnom sudu Republike Hrvatske ('Narodne novine', broj 13/91), što je učinjeno u točki I.2. odluke. U određenom roku od šest mjeseci zakonodavac može na odgovarajući način urediti pretpostavke za otkaz u smislu odredbe članka 40. stavka 1. podstavka 1. Zakona o najmu.

Uz navedeno, odredba članka 40. stavka 1. podstavka 2., u kojem slučaju drugi odgovarajući stan najmoprimcu obvezno osigurava jedinica lokalne samouprave 
odnosno Grad Zagreb, ne može biti od utjecaja na ocjenu ovdje osporene odredbe stavka 2.'.

U privitku ovog Izvješća dostavljamo odluku Ustavnog suda broj: U-I-762/1996 od 31. ožujka 1998.

2. Vlada Republike Hrvatske izvijestila je Ustavni sud da je na 29. sjednici Hrvatskog sabora, održanoj 29. siječnja 2003., provedena rasprava u prvom čitanju o Prijedlogu zakona o izmjenama i dopunama Zakona o najmu stanova.

Ustavni sud primjećuje da Hrvatski sabor u razdoblju od dana objave navedene odluke Ustavnog suda (6. travnja 1998.) do nastupa njezinog ukidnog učinka (6. listopada 1998.) nije izmijenio ni dopunio članak 40. Zakona o najmu stanova u skladu s pravnim stajalištem izraženim u navedenoj odluci Ustavnog suda niti je to učinio do dana utvrđenja ovog Izvješća.

3. U razdoblju nakon odluke Ustavnog suda, odnosno prestanka važenja ukinute zakonske odredbe, vlasnici stanova (najmodavci) pokrenuli su brojne postupke pred nadležnim sudovima radi otkaza ugovora o najmu stanova, pozivom na odredbe članka 40. stavka 1. podstavka 1. Zakona o najmu stanova.

Prema evidenciji ustavnosudskih predmeta, Ustavnom sudu podnijete su ustavne tužbe protiv presuda kojima su sudovi odlučivali o tužbenim zahtjevima vlasnika stanova (najmodavaca) o iseljenju najmoprimaca, a da u Zakonu o najmu stanova prethodno nisu utvrđene pretpostavke tog iseljenja. Ustavne tužbe podnijeli su, ovisno o presudi, vlasnici stanova, odnosno najmoprimci jer smatraju da su im tim presudama povrijeđena ustavna prava.

U povodu takvih ustavnih tužbi, Ustavni sud je u dva slučaja (U-III-135/2003, U-III-485/2006) odgodio ovrhu presuda nadležnih sudova o iseljenju najmoprimaca do donošenja odluke o ustavnoj tužbi. Ustavni sud nije donio odluku o ustavnim tužbama u navedenim predmetima jer ukidna odluka Ustavnog suda od strane Hrvatskog sabora nije provedena, što je pretpostavka za meritorno odlučivanje o tim ustavnim tužbama.

4. Prema odredbama članka 31. Ustavnog zakona o Ustavnom sudu Republike Hrvatske (u daljnjem tekstu: Ustavni zakon), odluke Ustavnog suda su obvezatne te su sva tijela državne vlasti dužna u okviru svog ustavnog i zakonskog djelokruga provoditi odluke Ustavnog suda.

Ustavni sud napominje da u okviru svoje nadležnosti nema ovlasti otkloniti nejednakost u primjeni Zakona o najmu stanova, nastalu prestankom važenja ukinute zakonske odredbe. Odluke Ustavnog suda (usvajanje, odnosno odbijanje 
ustavne tužbe) dovele bi do daljnje nejednakosti pred zakonom, što je protivno ustavnom jamstvu sadržanom u članku 14. stavku 2. Ustava. Stoga je postojeća normativna situacija s ustavnopravnog stajališta neprihvatljiva i nedopustiva jer ne rješava problem u cijelosti i na jednak način za sve glede primjene Zakona o najmu stanova.

Slijedi da je jedino zakonodavac nadležan, donošenjem odgovarajućih izmjena i dopuna Zakona o najmu stanova, urediti sporne pravne odnose na način koji će osigurati jednakost svih pred zakonom.

5. Prateći ostvarivanje ustavnosti i zakonitosti te imajući u vidu obvezatnost provedbe odluka Ustavnog suda (članak 31. Ustavnog zakona), na temelju članka 128. alineje 5. Ustava Republike Hrvatske i članka 104. Ustavnog zakona, Hrvatskom saboru upućuje se ovo Izvješće.“

Iako se radi o pojedinom slučaju neizvršavanja odluke Ustavnog suda od strane Hrvatskog sabora, on u kontekstu ovog rada zaslužuje pozornost barem iz dva razloga. Prvo, moglo bi se raditi o slučaju kada ,zakonodavac namjerno ne regulira neko pitanje prepuštajući praksi da ovo riješi." ${ }^{23}$

No, u takvoj situaciji, kad postoji pravna praznina jer zakonodavac nešto nije riješio ili ne želi riješiti, Ustavni sud nije nadležan odlučivati u postupku ocjene ustavnosti zakona te ustavnosti i zakonitosti drugih propisa odnosno pojedinih njegovih odredaba.

Sudu preostaju samo pravo i dužnost da, ukoliko zbog takve pravne praznine odnosno zakonodavnog propusta uoči neustavnost i nezakonitost, izvijesti Hrvatski sabor. Drugo, u ustavnopravnom poretku „Republike Hrvatske ne postoje mehanizmi kojima bi se Hrvatski sabor ili Vlada Republike Hrvatske prisilili na izvršenje odluka Ustavnog suda kojima se ukidaju zakoni ili drugi propisi, odnosno pojedine njihove odredbe, zbog nesuglasnosti s Ustavom", ${ }^{24}$ odnosno nesuglasnosti s ustavom i zakonom kad su u pitanju drugi propisi. Ako se za takvu opciju opredijeli zakonodavac, i uz njegovu (makar i prešutnu) suglasnost Vlada Republike Hrvatske, kad je donošenje propisa ili pojedine njegove odredbe u njezinoj ovlasti, članak 31. Ustavnog zakona o Ustavnom sudu Republike Hrvatske, usprkos svim svojim dobrim rješenjima, ostaje samo golo slovo na papiru. Dakako, time ne ulazimo u druge oblike, uključivo i političke, njihove odgovornosti zbog kojih bi se mogao vršiti utjecaj na njih da neustavnosti i nezakonitosti koje su posljedica pravnih praznina ili zakonodavnog propusta nastalih stupanjem na snagu ukidajućih odluka Ustavnog suda, otklone.

23 Vuković, Đ.: Pravna država, Zgombić i Partneri, Zagreb, 2005., str. 108.

24 Arlović, M.; ,Međuodnos između pozitivnog i negativnog zakonodavca u Republici Hrvatskoj“, Pravni vjesnik Pravnog fakulteta u Osijeku, broj 3-4/2015., str. 257. 


\section{NADZOR NAD DONOŠENJEM PROPISA ZA IZVRŠAVANJE USTAVA, ZAKONA I DRUGIH PROPISA I PRAVNE PRAZNINE}

Nadzor nad donošenjem propisa za izvršavanje ustava, zakona i drugih propisa jedna je od nadležnosti Ustavnog suda Republike Hrvatske koju članak 129. Ustava podvodi pod alineju „obavlja druge poslove određene Ustavom“. Baš zato je ova nadležnost kao tzv. drugi posao također regulirana Ustavom i to člankom 30. koji se u sadržajnom smislu u cijelosti odnosi na reguliranje ove djelatnosti. Sam način postupanja Ustavnog suda u ovim slučajevima nadzora uređen je normama članka 105. Ustavnog zakona o Ustavnom sudu Republike Hrvatske. Njime je određeno postupanje u dva slučaja provođenja nadzora nad donošenjem propisa za izvršavanje Ustava, zakona i drugih propisa. Prvo, prema članku 105. stavku $1 .{ }^{25}$ radi se o situaciji „,kad Ustavni sud utvrdi da nadležno tijelo nije donijelo propis za izvršenje odredaba Ustava, zakona i drugih propisa, a bilo je dužno takav propis donijeti, o tome će obavijestiti Vladu Republike Hrvatske.“ Drugo, prema stavku 2. istog članka, ,kad Ustavni sud utvrdi da Vlada Republike Hrvatske nije donijela propis za izvršenje odredaba Ustava, zakona i drugih propisa, o tome će obavijestiti Hrvatski sabor." Dakako, po prirodi stvari, ali i temeljem obveze utvrđene u stavku 3. ovog članka, izvješće o provedenom nadzoru u slučaju iz stavka 1. ovog članka dostavlja se u pisanom obliku predsjedniku Vlade Republike Hrvatske, a izvješće iz stavka 2. ovoga članka predsjedniku Hrvatskoga sabora.

Specifičnost ustavnopravne situacije koja nastaje kad u provedenom postupku nadzora nad donošenjem propisa za izvršenje Ustava, zakona i drugih propisa Ustavni sud utvrdi da nadležno tijelo nije donijelo takav propis, on je volens nolens utvrdio postojanje pravne praznine, a ako se radi o propisu za izvršenje Ustava, onda se u pravilu radi o zakonodavnom propustu. Navedene pravne praznine i zakonodavni propust po prirodi stvari imaju negativan utjecaj na ostvarivanje vladavine prava, a osobito njezinih sadržajnih elemenata izraženih u načelima ustavnosti i zakonitosti te pravne sigurnosti. Pogotovo teške posljedice po ova načela izaziva zakonodavni propust kada se ne donese propis (ustavni zakon ili zakon) za izvršavanje Ustava. Sama obveza donošenje propisa za izvršavanje Ustava, odnosno pojedinih njegovih odredaba, upućuje na zaključak da se radi o takvim odredbama Ustava koje nisu podesne za neposrednu primjenu. Nedonošenjem propisa za izvršenje Ustava de facto i de iure onemogućuje se njegova primjena i poštovanje, što za posljedicu ima povredu svih najviših vrednota ustavnog poretka, a osobito među njima vladavine prava te ustavnosti i zakonitosti i pravne sigurnosti.

Izvještavajući Vladu Republike Hrvatske odnosno Hrvatski sabor o provedenome nadzoru kojim je utvrdio da nadležna tijela nisu donijela odgovarajuće propise za izvršenje Ustava, zakona i drugih propisa, Ustavni sud istovremeno ova tijela upozorava: a) postojanje pravnih praznina i zakonodavnih propusta dovodi do poroznosti ustavnopravnog poretka kojim narušavaju njegovu konzistentnost, tekst.

25 Ustavni zakon o Ustavnom sudu Republike Hrvatske, Narodne novine, broj 49/2002. - pročišćeni 
jedinstvenost, primjenjivost $\mathrm{i}$ djelotvornost, b) tako nastale pravne praznine $\mathrm{i}$ zakonodavni propusti stalni su uzročnici povrede načela ustavnosti i zakonitosti, pravne sigurnosti i vladavine prava i kao načela i kao jedne od najviših vrednota ustavnog poretka, s kontinuiranim i razornim učinkom po njih i na cjelokupnu djelotvornost te stabilnost ustavnog pravnog poretka; dakako, za svaki nedoneseni propis razmjerno njegovu položaju u hijerarhiji pravnoga sustava te ulozi i značaju za izvršavanje višeg propisa zbog čega ga je trebalo donijeti, c) Ustavni sud nije nadležan izvorno odlučivati o postojanju pravnih praznina i zakonodavnih propusta ni ocjenjivati njihovu ustavnost i zakonitost, ali nadležan je postupiti prema njima i, kad utvrdi takvu situaciju, svojim izvješćima izvijestiti nadležna tijela čime će im, kao kreatorima zakonodavne politike i njezine provedbe, omogućiti da poduzmu odgovarajuće aktivnosti kako bi ispunila svoju ustavnu odnosno zakonsku obvezu i donijela propis potreban za izvršenje Ustava, zakona i drugog propisa. Time je svoju ulogu kao negativnog zakonodavca Ustavni sud ispunio kroz jedan specifični oblik ustavnosudskog aktivizma prema pozitivnom zakonodavcu.

Dosadašnja ustavnosudska praksa Ustavnog suda Republike Hrvatske uključuje i takve situacije kada on, pozivom na članak 30. Ustava u vezi sa člankom 105. Ustavnog zakona o Ustavnom sudu, podnosi Izvješće zbog nedonošenja propisa potrebnih za izvršenje viših pravnih akata ili njihovo donošenje nakon proteka utvrđenoga roka. Ilustracije radi, podsjećam na Izvješće Hrvatskom saboru broj: U-X-835/2005 od 24. veljače 2005. godine. Tim Izvješćem Ustavni sud je, pored ostaloga, upozorio na to da se "podzakonski propisi često donose nakon proteka zakonom određenog roka za njihovo donošenje, a što nije u skladu s načelom ustavnosti i zakonitosti."

Zapravo, u obje ove svoje djelatnosti, neovisno o tome radi li se o praćenju ostvarivanja ustavnosti i zakonitosti, ili se radi o nadzoru nad donošenjem propisa za izvršenje Ustava, zakona i drugih propisa, Ustavni sud njihovim ostvarivanjem dolazi u poziciju da otkriva postojanje pravnih praznina, odnosno zakonodavnog propusta te da, pripremajući svoje izvješće, sagleda njihov utjecaj na ostvarivanje vladavine prava, ustavnosti i zakonitosti, pravne sigurnosti i, u krajnjoj liniji, djelotvornosti ustavnopravnog sustava. Sud svojim Izvješćem upućuje na uočene pojave nadležna tijela, istovremeno im otvarajući prostor da što prije, u okviru svoj djelokruga, kao pozitivni zakonodavci poduzmu pravne radnje donošenjem potrebnog pravnog propisa ili izmjenom i dopunom njihovih odredaba i time iz pravnog sustava otklone pravne praznine odnosno isprave zakonodavni propust.

Iz izloženoga je razvidno da su ova izvješća veoma važan instrument djelovanja Ustavnoga suda u provođenju zadaće poštovanja i primjene Ustava. Prije svega, zbog toga što najvišim tijelima zakonodavne i izvršne vlasti kroz njih daje informaciju o uočenim pojavama i o tome što bi oni u okviru svoje nadležnosti trebali poduzeti radi provođenja načela ustavnosti i zakonitosti, te vladavine prava i pravne sigurnosti. Baš zbog takvog značaja ovih Izvješća i iz članka 104. i članka 
Dr. sc. Mato Arlović: Ustavni okvir djelovanja Ustavnog suda Republike Hrvatske za ispitivanje... Zbornik radova Pravnog fakulteta u Splitu, god. 54, 1/2017., str. 255.-281.

105. Ustavnog zakona o Ustavnom sudu Republike Hrvatske, propisuje da se o njima odlučuje na sjednici Ustavnoga suda. ${ }^{26}$

\section{O PRAVNIM PRAZNINAMA U POSTUPCIMA POVODOM USTAVNIH TUŽBI}

Ljudska prava i temeljne slobode u ustavnopravnom sustavu Republike Hrvatske, kao i u drugim ustavnim demokratskim državama, vladavina prava jedan je od bitnijih elemenata njezine konstitucionalizacije. ${ }^{27}$ Hrvatski ustavotvorac takav pristup ljudskim pravima i temeljnim slobodama, pored ostalih osnova, potvrđuje: a) time što se ona utvrđuju, reguliraju i štite samim ustavom odnosno normama ustavnog prava, dok se zakonima ona razrađuju, ${ }^{28}$ b) njihova zaštita podignuta je u krajnjoj liniji na unutrašnjem planu na Ustavni sud Republike Hrvatske, a na nadnacionalnoj razini na Europski sud za ljudska prava u Strasbourgu, c) time što je hrvatski ustavotvorac pravnim aktima nadnacionalnog prava kojima se ona reguliraju u smislu članka $141 .{ }^{29} \mathrm{u}$ hijerarhiji pravnih propisa dodijelio pravnu snagu iznad zakona, ali doduše ispod ustava $\mathrm{i}$ d) time što je svojom ustavnosudskom praksom Ustavni sud Republike Hrvatske Konvenciju za zaštitu ljudskih prava i temeljnih sloboda prihvatio kao subustavni pravni akt. ${ }^{30}$ Takva ustavnopravna pozicija ljudskih prava i temeljnih sloboda tražila je njihovo ustavno zajamčenje $s$ jedne strane, a s druge da se njihova zaštita propiše normama ustavnog prava i to pred Ustavnim sudom.

Slijedom toga, logično je opredjeljenje hrvatskog ustavotvorca kojim je u Ustavnom zakonu o Ustavnom sudu Republike Hrvatske, svojim člankom 62., odlučio propisati:

„(1) Svatko može podnijeti Ustavnom sudu ustavnu tužbu ako smatra da mu je pojedinačnim aktom tijela državne vlasti, tijela jedinice lokalne i područne (regionalne) samouprave ili pravne osobe s javnim ovlastima, kojim je odlučeno o njegovim pravima i obvezama ili o sumnji ili optužbi zbog kažnjivog djela, povrijeđeno ljudsko pravo ili temeljna sloboda zajamčena Ustavom, odnosno

26 Isto; vidjeti pobliže članak 104. stavak 2. i članak 105. stavak 4.

27 Više o konstitucionalizmu kao teorijskom konceptu moderne ustavne demokratske države ljudskih prava i temeljnih sloboda te vladavine prava kod Bačić, A.: Hrvatska i izazovi konstitucionalizma, Split, 2011 .

28 Vidjeti pobliže članak 83. stavak 2. Ustava Republike Hrvatske, Narodne novine, broj 85/2010. pročišćeni tekst.

29 Isto; članak 141. glasi: „Međunarodni ugovori koji su sklopljeni i potvrđeni u skladu s Ustavom i objavljeni, a koji su na snazi, čine dio unutarnjega pravnog poretka Republike Hrvatske, a po pravnoj su snazi iznad zakona. Njihove se odredbe mogu mijenjati ili ukidati samo uz uvjete i na način koji su u njima utvrđeni, ili suglasno općim pravilima međunarodnog prava."

30 Pojam „subustavan“ preuzeo sam od J. Omejec, bivše predsjednice Ustavnog suda Republike Hrvatske, vidjeti njezin rad: „Novi europski tranzicijski ustav i transformativna uloga ustavnih sudova“, u Dvadeseta obljetnica Ustava Republike Hrvatske, Zbornik radova HAZU-a, Zagreb, 2011., str. 61-85. 
Ustavom zajamčeno pravo na lokalnu i područnu (regionalnu) samoupravu (u daljnjem tekstu: ustavno pravo).

(2) Ako je zbog povrede ustavnih prava dopušten drugi pravni put, ustavna tužba može se podnijeti tek nakon što je taj pravni put iscrpljen.

(3) U stvarima u kojima je dopušten upravni spor, odnosno revizija u parničnom ili izvanparničnom postupku, pravni put je iscrpljen nakon što je odlučeno i o tim pravnim sredstvima.“

Postupajući u postupcima pokrenutima ustavnom tužbom, kao postupcima kontrole i zaštite Ustavom zajamčenih ljudskih prava i temeljnih sloboda, Ustavni sud se susretao (izravno ili neizravno) s pitanjem pravnih praznina. U tim je postupcima Ustavni sud Republike Hrvatske raspravljao i ocjenjivao je li u sudskim (i/ili upravnim) postupcima nadležno tijelo postojeće pravne praznine interpretiralo u skladu s Ustavom, odnosno, još točnije, u skladu s ustavom zajamčenim pravima i temeljnim slobodama. Drugim riječima, je li takvom interpretacijom utvrdilo, prihvatilo i primijenilo pravno pravilo kojim, doduše, popunjava pravnu prazninu, ali ga primjenom na konkretni slučaj donosi odlukom kojom jest ili nije osiguralo zaštitu i ostvarenje ljudskih prava.

Iz ustavnosudske prakse Ustavnog suda Republike Hrvatske ${ }^{31}$ za ocjenjivanje i odlučivanje o pravnim prazninama povodom ustavnih tužbi iskristalizirale su se tri vrste predmeta.

Prva se može ilustrirati sljedećim primjerom.

U predmetu broj: U-III-1621/2001 od 30. ožujka 2005., Ustavni sud je odlučivao o ustavnoj tužbi kojom je podnositeljica, među inim, navela i povredu prava na jednakost svih pred zakonom, prava na rad, zaradu i socijalnu sigurnost, koje su joj učinjene odlukom Vrhovnog suda Republike Hrvatske. Tom je odlukom Vrhovnog suda okončan radni spor, a podnositeljici je prestao radni odnos, jer je od poslovne jedinice bivšeg poduzeća osnovano novo poduzeće i to temeljem Uredbe o zabrani raspolaganja i prijenosa sredstava određenih pravnih osoba na teritoriju Republike Hrvatske (Narodne novine broj 52/1991.). Ustavni sud je svojom gore navedenom odlukom ukinuo presudu Vrhovnog suda Republike Hrvatske, uz obrazloženje:

„Ustavni sud Republike Hrvatske ne nalazi utemeljenim izloženo stajalište revizijskog suda. To iz razloga, jer je odredbom članka 6. Uredbe iz 1991. priznato pravo djelatnicima poslovne jedinice da svojom odlukom utvrde budući organizacijski oblik, a što podrazumijeva i pravo da odluče o svom radnopravnom statusu. U suprotnom, to bi organiziranje bilo na štetu djelatnika, a što nije u skladu s legalnom svrhom same Uredbe, koja je i bila donesena radi zaštite gospodarskih interesa Republike Hrvatske u tadašnjim okolnostima.

31 Vidjeti pobliže i vrlo informativan te stručno pripremljen materijal Ustavnog suda Republike Hrvatske koji je izrađen u obliku odgovora na Upitnik za XIV. Kongres Konferencije europskih ustavnih sudova, predmet broj: SuP-MS-2/2008. 
Potrebno je istaći i to, da se navedena Uredba iz 1991. unatoč tome što izričito ne uređuje radnopravne odnose i radnopravni status zatečenih djelatnika, ne može zbog postojanja pravne praznine tumačiti na štetu radnika. Ako bi se, naime, prihvatilo stajalište Vrhovnog suda, onda bi se moglo zaključiti i to, da se nova pravna osoba ima pravo organizirati, bez ikakve obveze da u trenutku organiziranja ima ijednog zaposlenog, što nedvojbeno nije bila svrha Uredbe.“

Ovakvo svoje stajalište Ustavni sud je zauzeo i u drugim istovrsnim predmetima. Vidi npr. u predmetu broj: U-III-1027/1998 od 26. siječnja 2001. godine.

Drugo, skupina predmeta u kojima se povodom ustavne tužbe Ustavni sud susretao s pravnim prazninama, vezana je uz prigovore podnositelja da im je povrijeđeno pravo na suđenje u razumnom roku i pravo na pristup sudu u parnicama koje su vodili za naknadu štete prouzročenih terorističkim aktima, ili od pripadnika Hrvatske vojske i redarstvenih snaga povezano s obavljanjem njihove službe tijekom Domovinskog rata. Glede ovih pitanja koje su isticali podnositelji ustavnih tužbi, zakonodavac je u izmjenama i dopunama Zakona o obveznim odnosima ${ }^{32}$ propisao instruktivan rok zakonodavcu za donošenje novih propisa. On se, ni približno, tog roka nije pridržavao, već je propise donio znatno kasnije. No, za vrijeme trajanja te pravne praznine (jer se nisu donijeli posebni propisi), nadležni sudovi su bili silom (izmijenjenog i dopunjenog ZOO-a) onemogućeni tijekom prekida poduzimati radnje povezane s odlučivanjem o podnesenim tužbenim zahtjevima. Nastala pravna praznina je po ostvarivanje i zaštitu ljudskih prava za Ustavni sud nesporno imala negativan utjecaj. Naime, u odlukama Suda, primjerice odluka broj: U-IIIA-892/2002 od 7. srpnja 2004., utvrđeno je da je zbog takvog postupanja redovnih sudova (koji su morali poštovati pravnu prazninu izazvanu zakonodavnim propustom neaktivnošću zakonodavca) došlo do povrede prava na suđenje u razumnom roku i povrede prava na pristup sudu, te je usvajao ustavne tužbe, a podnositeljima dosuđivao primjerene naknade za povredu tih ustavnih prava.

Treće, određena vrsta postupaka koji dovode do odlučivanja o pravnim prazninama povodom ustavne tužbe, vezana je na članak 63. Ustavnog zakona o Ustavnom sudu Republike Hrvatske. Naime, njime je utvrđena iznimka koja od Ustavnog suda traži pokretanje postupka po ustavnoj tužbi i prije nego je iscrpljen pravni put. Dakako, u slučaju kad o pravima i obvezama stranke ili o sumnji ili optužbi zbog kažnjivog djela nije u razumnom roku odlučio sud ili u slučaju kad se osporenim pojedinačnim aktom grubo vrijeđaju ustavna prava, a potpuno je razvidno da bi nepokretanjem ustavnosudskog postupka za podnositelja ustavne tužbe mogle nastati teške i nepopravljive posljedice. ${ }^{33}$

Pored gore navedenog sudjelovanja i odlučivanja o pravnim prazninama od strane Ustavnog suda, valja podsjetiti da je hrvatski ustavotvorac propisao i zadaće

\footnotetext{
7/1996.)

33 Vidjeti pobliže članak 63. Ustavnog zakona o Ustavnom sudu Republike Hrvatske, Narodne novine, broj 49/2002. - pročišćeni tekst.
}

32 Radi se o izmjenama i dopunama Zakona o obveznim odnosima iz 1996. (Narodne novine, broj 
donositeljima takvih akata koji su bili uzrokom povrede ljudskih prava i temeljnih sloboda. Naime, u slučaju kad Ustavni sud usvoji ustavnu tužbu i tom odlukom ukine osporeni (pojedinačni) akt, nadležno sudbeno ili upravno tijelo, tijelo jedinice lokalne i područne (regionalne) samouprave ili pravne osobe s javnim ovlastima čiji akt je ukinut - dužno je umjesto njega donijeti novi akt. ${ }^{34}$ Kod donošenja novog akta ta su tijela obvezna poštovati pravna stajališta Ustavnog suda zauzeta u odluci koja ukida akt kojim je povrijeđeno ljudsko pravo i temeljna sloboda podnositelja ustavne tužbe. ${ }^{35}$

Na kraju ovoga rada nije suvišno ukazati na to da je hrvatski ustavotvorac Ustavnom sudu dao mehanizam kojim, kad utvrdi da njegova ukidajuća odluka (iz apstraktne kontrole) može dovesti do postojanja pravne praznine u pravnom poretku, može u cijelosti ili barem u značajnoj mjeri otkloniti njezine negativne učinke po vladavinu prava i pravnu sigurnost. Ustavnim zakonom o Ustavnom sudu Hrvatskom je ustavnom sudu dana mogućnost primjene tzv. odgodnog roka. ${ }^{36}$ Ovaj ustavni institut omogućuje Ustavnom sudu Republike Hrvatske da, ovisno o svakom pojedinom slučaju, uvijek razmotri vrijeme potrebno zakonodavcu za donošenje novog zakona ili drugog propisa ili samo pojedine odredbe te da to vrijeme odredi polazeći od vrste i opsega ukinutog akta odnosno njegovih pojedinih odredbi, njihova značaja i utjecaja na društvene odnose. U svojoj ustavnosudskoj praksi Ustavni sud Republike Hrvatske se više puta (ali ne previše) poslužio odgodnim rokom, tako npr. u svojoj odluci broj: U-I-1569/2004 od 20. prosinca 2006. itd.

\section{ZAKLJUČNE NAPOMENE}

Nema dvojbe da su pravne praznine odnosno zakonodavni propusti prateća pojava svakog ustavnopravnog sustava - u većoj ili manjoj mjeri. One imaju negativno djelovanje na konzistentnost i cjelovitost pravnog sustava, ali i na ostvarivanje njime propisane vladavine prava, pravne sigurnosti te ustavnosti i zakonitosti.

Posljedica su različitih uzroka, od kojih je svakako najznačajniji onaj koji proizlazi iz nesavršenosti pravnog sustava i njegove nemogućnosti da unaprijed predvidi potrebnu pravnu regulaciju razmjerno širenju i razvoju postojećih te nastajanju novih društvenih odnosa. U svojoj biti one su odlučujući dokaz koji potvrđuje da se život uvijek brže razvija nego što to može predvidjeti pravo.

Ustavnopravni poreci svojim propisima predviđaju mogućnosti i propisuju osnove sudbenim, upravnim i drugim tijelima lokalne, regionalne ili druge javne vlasti kako da se u postupcima odlučivanja i primjene prava nose s pravnim prazninama odnosno zakonodavnim propustima. Dakako, radi se o primjeni različitih metoda interpretacije pravnih propisa i njihovih odredaba koje bi se analogijom mogle primijeniti na konkretan slučaj. Tako nastalo pravilo koje je primijenjeno za neki

34 Isto; vidjeti pobliže članak 76.

35 Isto; vidjeti pobliže članak 77. stavak 2.

36 Isto; članak 55. stavak 2. 
slučaj u europskom kontinentalnom pravu, u pravilu važi samo za taj slučaj i nije, niti može biti, izvorom prava ni za koga, uključivo ni za tijelo koje ga je stvorilo kad rješava neki novi konkretni predmet.

Kad je u pitanju rješavanje konkretnih predmeta pravne praznine odnosno zakonodavni propusti često puta bivaju uzroci koji dovode do povrede načela jednakosti pa i diskriminiranosti. Stoga su oni isključeni i zabranjeni u kaznenom pravu.

Pravne praznine i zakonodavni propusti imaju utjecaja kako na strukturu tako i na provedbu pravnog poretka. Zbog toga jesu od značaja i za ustavnopravnu teoriju i za ustavnosudsku praksu.

U ustavnopravnom sustavu Republike Hrvatske pravne praznine odnosno zakonodavni propisi expressis verbis niti se ne spominju. To, dakako, ne znači da ne postoje.

Prihvaćajući činjenice da se izrijekom pravne praznine u ustavnopravnom poretku ne spominju, razumljivo je stajalište hrvatskog ustavotvorca da prilikom propisivanja nadležnosti Ustavnom sudu Hrvatske o mogućnosti odlučivanja o pravnim prazninama odnosno zakonodavnim propisima - nije ništa propisao. Slijedom toga, Ustavni je sud zauzeo čvrsto stajalište da o njihovoj ustavnosti i zakonitosti ne odlučuje.

Međutim, takva ustavna situacija istodobno ne znači da se Ustavni sud ne susreće s pravnim prazninama i zakonodavnim propustima i da ih ne propituje. Susreće se s njima u apstraktnoj kontroli ustavnosti zakona, ustavnosti i zakonitosti drugih propisa, ali i postupajući u konkretnim ustavnim sporovima radi zaštite ljudskih prava i temeljnih sloboda zajamčenih Ustavom. Osim toga, nailazi na njih i u provođenju svojih drugih nadležnosti utvrđenih Ustavom i Ustavnim zakonom o Ustavnom sudu, a to su: a) praćenje ostvarivanja ustavnosti i zakonitosti, b) nadzor nad donošenjem propisa za izvršavanje Ustava, zakona i drugih propisa. O postupanju Ustavnog suda Hrvatske glede pravnih praznina i zakonodavnih propusta te o aktivnostima koje može poduzimati, bavio se ovaj rad, pa ih neću ponovno ponavljati.

Zaključno treba možda ipak naglasiti:

Prvo, Ustavni je sud utvrdio da o postojanju pravnih praznina i zakonodavnih propusta nije nadležan odlučivati u postupcima ocjene ustavnosti zakona, te ustavnosti i zakonitosti drugih propisa.

Drugo, u postupcima apstraktne kontrole, pored inog, kada utvrdi pravne praznine i zakonodavne propuste, u pravilu ili dostavlja izvješće Hrvatskom saboru o uočenoj pojavi neustavnosti odnosno nezakonitosti ili u okviru svoje nadležnosti provođenja nadzora nad donošenjem propisa za izvršenje Ustava, zakona i drugih propisa izvješćuje Vladu ili Hrvatski sabor kako nadležno tijelo koje je dužno donijeti propis isti nije donijelo bilo u cijelosti bilo djelomično. Time doprinosi otklanjanju, točnije popunjavanju, pravnih praznina odnosno zakonodavnog propusta. 
Prema tome, s pravom možemo reći da Ustavni sud Republike Hrvatske ima na raspolaganju određene (drugo je pitanje jesu li u cijelosti dostatni) pravne instrumente za preispitivanje pravnih praznina. Njegova ustavnosudska praksa pokazuje da se njima koristi i tako, kroz popunjavanje pravnih praznina i zakonodavnog propusta, jednim dijelom manifestira ustavnosudski aktivizam utječući na nastajanje zakona i drugih propisa.

U obavljanju ove djelatnosti, između Ustavnog suda i zakonodavca ostvaruju se odnosi suradnje i uzajamne provjere s jedne strane, a s druge strane ublažuje se oštrina granice između njih kao negativnog i pozitivnog zakonodavca.

\section{Literatura}

1. Arlović, M.; „Međuodnos između pozitivnog i negativnog zakonodavca u Republici Hrvatskoj“, Pravni vjesnik Pravnog fakulteta u Osijeku, 3-4/2015.

2. Arlović, M.: „Ocjena zakonitosti općih akata u Zakonu o upravnim sporovima: O nekim otvorenim pitanjima“, Pravni vjesnik Pravnog fakulteta, Osijek, br. 3-4/2011.

3. Arlović, M.: „Ustavnosudski aktivizam i europski pravni standardi“, Zbornik radova Pravnog fakulteta u Splitu, br. 1/2014.

4. Bačić, A.: Hrvatska i izazovi konstitucionalizma, Split, 2011.

5. Belajac, V.: „Ustavne osnove za podnošenje ustavne tužbe“, u: Ustavni sud u zaštiti ljudskih prava, Pravo, broj 24., Organizator, Zagreb, 2000.

6. Borković, I.: Upravno pravo, II. izdanje, Zagreb, 2002.

7. Crnić, J.: Komentar Ustavnog zakona o Ustavnom sudu Republike Hrvatske, Zagreb, 2002.

8. Häberle, P.: Ustavna država, Zagreb, 2002.

9. Ivančević, V.: Institucije upravnog prava, Knjiga I., Zagreb, 1983.

10. Kelsen, H.: Opća teorija prava i države, Arhiv za pravne i društvene nauke, Beograd, 1951.

11. Krbek, I.: Ustavno sudovanje, JAZU, Zagreb, 1960.

12. Lukić, R.: Uvod u pravo, Beograd, 1964.

13. Muhić, F.: Teorija države i prava, Sarajevo, 1998.

14. Omejec, J.: „Novi europski tranzicijski ustav i transformativna uloga ustavnih sudova“, u: Dvadeseta obljetnica Ustava Republike Hrvatske, Zbornik radova HAZU-a, Zagreb, 2011.

15. Perić, B.: Država i pravni sustav, Informator, Zagreb, 1994.

16. Smerdel, B.: Ustavno uređenje europske Hrvatske, Zagreb, 2013.

17. Smerdel, B. i Sokol, S.: Ustavno pravo, Pravni fakultet Sveučilišta u Zagrebu, 2006.

18. Sokol, S.: „Ustavni sud Republike Hrvatske u zaštiti i promicanju vladavine prava“, Zbornik Pravnog fakulteta Zagreb, broj 6/2001.

19. Visković, N.: Država i pravo, Birotehnika, Zagreb, 1997.

20. Vrban, D.: Država i pravo, Golden marketing, Zagreb, 2003. 
21. Vuković, Đ.: Pravna država, Zgombić i Partneri, Zagreb, 2005.

22. Materijal Ustavnog suda Republike Hrvatske, predmet broj: SuP-MS-2/2008.

23. Ustav Republike Hrvatske, Narodne novine, broj 85/2010. - pročišćeni tekst.

24. Ustavni zakon o Ustavnom sudu Republike Hrvatske, Narodne novine, broj 49/2002. - pročišćeni tekst.

25. Zakon o izmjenama i dopunama Zakona o obveznim odnosima, Narodne novine, broj $7 / 1996$.

\section{CONSTITUTIONAL FRAMEWORK OF THE ACTIVITY OF THE CONSTITUTIONAL COURT OF THE REPUBLIC OF CROATIA FOR EXAMINING AND EVALUATING THE CONSTITUTIONALITY OF LEGAL GAPS}

This paper considers determination of the concept of legal gaps from a doctrinarian aspect and constitutional court practice. An attempt is made to observe the influence of legal gaps on the basis of values and principles of constitutional legal order as a whole. Then considered is what the authority of the Croatian Constitutional Court is in uncovering legal gaps. Also considered is the role of the Croatian Constitutional Court in removing these gaps from the constitutional legal order in order to prevent their action on the instability of the constitutional legal order by threatening the rule of law, legal security and the principle of constitutionality and legality.

Key words: legal gaps, supervision over bringing in regulations for implementing the Constitution, laws and other regulations, constitutional lawsuits, human rights and fundamental freedoms, rule of law, constitutionality and legality, legal security, reports 